OPEN ACCESS

Edited by:

Hari S. Misra,

Bhabha Atomic Research Centre

(BARC), India

Reviewed by:

Herve Seligmann,

Karlsruhe Institut of Technology,

Germany

Martin Kollmar,

Max Planck Institute for Biophysical

Chemistry, Germany

*Correspondence:

Sandra Moreira

sandra.moreira.r@gmail.com

Omar Orellana

oorellan@med.uchile.cl

Specialty section:

This article was submitted to

Microbial Physiology and Metabolism,

a section of the journa

Frontiers in Microbiology

Received: 17 September 2020

Accepted: 21 December 2020

Published: 15 January 2021

Citation:

Arias L, Martínez F, González D,

Flores-Ríos R, Katz A, Tello M,

Moreira S and Orellana O (2021)

Modification of Transfer RNA Levels

Affects Cyclin Aggregation

and the Correct Duplication of Yeast

Cells. Front. Microbiol. 11:607693.

do: $10.3389 /$ fmicb.2020.607693

\section{Modification of Transfer RNA Levels Affects Cyclin Aggregation and the Correct Duplication of Yeast Cells}

\author{
Loreto Arias' ${ }^{1}$, Fabián Martínez¹, Daniela González¹, Rodrigo Flores-Ríos ${ }^{1}$, Assaf Katz ${ }^{1}$, \\ Mario Tello ${ }^{2}$, Sandra Moreira ${ }^{1 *}$ and Omar Orellana ${ }^{1 *}$ \\ ${ }^{1}$ Programa de Biología Celular y Molecular, Instituto de Ciencias Biomédicas, Facultad de Medicina, Universidad de Chile, \\ Santiago, Chile, ${ }^{2}$ Departamento de Biología, Facultad de Química y Biología, Universidad de Santiago de Chile, Santiago, \\ Chile
}

Codon usage bias (the preferential use of certain synonymous codons (optimal) over others is found at the organism level (intergenomic) within specific genomes (intragenomic) and even in certain genes. Whether it is the result of genetic drift due to GC/AT content and/or natural selection is a topic of intense debate. Preferential codons are mostly found in genes encoding highly-expressed proteins, while lowlyexpressed proteins usually contain a high proportion of rare (lowly-represented) codons. While optimal codons are decoded by highly expressed tRNAs, rare codons are usually decoded by lowly-represented tRNAs. Whether rare codons play a role in controlling the expression of lowly- or temporarily-expressed proteins is an open question. In this work we approached this question using two strategies, either by replacing rare glycine codons with optimal counterparts in the gene that encodes the cell cycle protein Cdc13, or by overexpression the tRNA Gly that decodes rare codons from the fission yeast, Schizosaccharomyces pombe. While the replacement of synonymous codons severely affected cell growth, increasing tRNA levels affected the aggregation status of Cdc13 and cell division. These lead us to think that rare codons in lowly-expressed cyclin proteins are crucial for cell division, and that the overexpression of tRNA that decodes rare codons affects the expression of proteins containing these rare codons. These codons may be the result of the natural selection of codons in genes that encode lowly-expressed proteins.

Keywords: transfer RNA, cell cycle, cyclin, codon usage, protein aggregation

\section{INTRODUCTION}

Degeneracy or redundancy of the genetic code implies that more than one codon (2, 4 or 6 codons) exist for 18 of the 20 genetically encoded amino acids. Codons encoding the same amino acid are called synonymous. Despite considerable information demonstrating that the choice of one synonymous codon over another is not random (Bulmer, 1991; reviewed in Quax et al., 2015), the term "silent" codons is still in use, since codon exchange does not alter protein sequences. Each organism has a defined codon usage bias (CUB). CUB greatly varies among species and within the same genome. 
Whether CUB is the result of mutational drift forced by the nucleotide composition of DNA and/or natural selection for translation efficiency or accuracy has been a matter of debate (Bulmer, 1991; Brandis and Hughes, 2016; Dilucca et al., 2018). The most frequent codons (optimal codons) in rapidly-growing unicellular organisms are usually decoded by highly-expressed tRNAs, and the less frequent codons (rare or non-optimal codons) are decoded by less-expressed tRNAs (Ikemura, 1985; Kanaya et al., 1999; Chaney and Clark, 2015; Quax et al., 2015). In these organisms, CUB may optimize or deoptimize translation (translation efficiency) for a group of related mRNAs, coordinating their expression. However, these interpretations are controversial since some researchers have established that codon usage is an important factor in protein expression in trypanosomatids (Jeacock et al., 2018), where protein concentration can be estimated from protein coding sequences, while in other studies it has been determined that translation elongation speed is independent of codon usage bias (Ingolia et al., 2011). Moreover, codon bias has been identified as a major factor in determining both mRNA (Presnyak et al., 2015) and protein levels (Zhou et al., 2016). However, the extent to which mRNA translation efficiency links codon bias to protein levels remains unclear. This issue has gained importance in recent years as it has been linked to many factors that affect gene expression, such as mRNA stability, protein levels, folding, and localization (Chaney and Clark, 2015; reviewed in Bali and Bebok, 2015; Buhr et al., 2016; Hanson and Coller, 2018). Among these factors, the effect of codon choice on codon reading speed is the least understood. Since protein folding is cotranslational for many proteins, codon changes that affect codon reading speed may also alter the folding of encoded proteins, leading to abnormal protein functioning. Experimental evidence and genome-wide analyses suggest that regions between protein domains are enriched in non-optimal codons, while structured domains are mostly encoded by optimal codons (Zhou et al., 2015). Despite these data, it is difficult to predict the synonymous mutations that lead to abnormal protein expression, folding, or function and the response of cells to these defects.

Lowly expressed proteins have a tendency to use rare codons. Even though there is a correlation between gene expression and rare codon use in various species (Hiraoka et al., 2009; Ray et al., 2014), it is still not clear if the tendency to use non-optimal codons plays a role in protein expression levels or in protein folding (Supek, 2016).

Other aspects of genetic information may be altered by the replacement of synonymous codons. It is relevant to consider these potential effects since cell function can be altered. It has been proposed that codons are selected to prevent off-frame translation after ribosomal slippage (ambush hypothesis) (Seligmann and Pollock, 2004; Seligmann, 2010, 2012, 2019; Køížek and Køížek, 2012), although this idea has been disputed (Morgens et al., 2013; Chatenay et al., 2017). Additionally, circular codes, that is, codes within the genetic code, have been proposed as playing a role in ensuring translation accuracy (Arquès and Michel, 1996). Proposed as primordial codes, they are conserved in evolution, with implications in the interaction of mRNAs with ribosomes and tRNAs
(Michel and Thompson, 2020). Codon bias may be implicated in the conservation of circular codes in organisms and replacement of synonymous codons may alter such codes.

Circadian-clock proteins of Neurospora crassa and a cyanobacterium are examples of how the replacement of non-optimal codons with optimal ones affects the function of encoded proteins (Xu et al., 2013; Zhou et al., 2013) and alters circadian rhythms. A close correlation between the translation of non-optimal codons and the level of decoding, tRNA has been revealed in the gene encoding the cystic fibrosis transmembrane conductance regulator (CFTR). The replacement of an optimal with a non-optimal codon affects the function of CFTR. This effect is compensated by the upregulation of tRNA decoding non-optimal codon (Kirchner et al., 2017). Based on the above mentioned, the classical role of tRNAs as adaptor molecules for the incorporation of amino acids in nascent proteins has been expanded by findings that demonstrate changes in global tRNA abundance in response to different cellular processes (Torrent et al., 2018; Yang et al., 2020).

Eukaryotic cell-cycle proteins (cyclins) appear to be enriched in non-optimal codons, with some differences that depend on the cell-cycle phase in which they are expressed. The levels of total tRNA and of some aminoacyl-tRNA synthetases are also cell-cycle dependent in yeast (Frenkel-Morgenstern et al., 2012). $\mathrm{Cdc13}$ is one of the most widely studied cyclins from the fission yeast, $S$. pombe. It forms a complex and activates Cdc2 (Cdk1), an important kinase in G2/M transition (Humaidan et al., 2018). Cdc13 is preferentially expressed during this transition. The complex travels to the nucleus and phosphorylates a number of substrates that are crucial for the progress of the cell cycle. Although the protein structure of $\mathrm{Cdc13}$ has not yet been determined, a secondary structure is predicted, and some relevant regions have been identified. Cdc13 has a conserved hydrophobic patch (MRGILTDW) that is not required for cells to undergo the $\mathrm{S}$ phase in vivo but is required to target $\mathrm{Cdc13}$ to the equivalent to the spindle pole body in yeast (SPB) and for mitosis (Basu et al., 2020). Mutation in this hydrophobic patch alters Cdc13 localization, preventing centrosomal localization at the onset of mitosis. Finally, the complex is degraded at the mitosis stage. Since $c d c 13$ contains several non-optimal codons, we hypothesize that the presence of non-optimal codons in $c d c 13$ is required to modulate the proper level of the $\mathrm{Cdc} 13$ protein. The variable levels of tRNAs during the cell cycle (FrenkelMorgenstern et al., 2012) may control the expression of $c d c 13$. To test this hypothesis, we followed two approaches: (1) to introduce synonymous mutations to replace non-optimal with optimal codons in $c d c 13$, and (2), to modify the concentration of tRNAs that decode non-optimal codons. Our results show that these alterations significantly affect both $\mathrm{Cdc13}$ distribution in soluble and aggregated fractions and cell duplication.

\section{MATERIALS AND METHODS}

\section{Yeast Strains and Media}

Schizosaccharomyces pombe 972h-Sleu1-32 (LP36) strain was used in homologous recombination experiments. 
Supplementary Table 1 lists the primers used in this study. $S$. pombe was grown on YES medium ( $5 \mathrm{~g} / \mathrm{l}$ of yeast extract, $30 \mathrm{~g} / \mathrm{l}$ of glucose), YPD (10 g/l of yeast extract, $20 \mathrm{~g} / \mathrm{l}$ of peptone, $20 \mathrm{~g} / \mathrm{l}$ of glucose), and Edinburgh minimal medium 2 (EMM2, United States Biological).

\section{Plasmid Construction for Homologous cdc13 Recombination}

The endogenous $c d c 13$ gene was replaced by a homologous recombination with the wild-type or mutated $c d c 13$, both containing a 7xHis-tag at the $3^{\prime}$ end. For the homologous recombination with the wild-type $c d c 13$ gene, we first cloned the flanking regions of the $\mathrm{Cdc13}$ coding sequence in the pFA6a-KanMX6 vector (Addgene), as described below. Flanking regions were amplified from $S$. pombe genomic DNA (gDNA), using Herculase II Fusion DNA polymerase (Agilent Genomics) in accordance with the manufacturer's instructions, using cdc13-histag forward and reverse primer sets as described in Supplementary Table 1. The digestion products were ligated to the pFA6a-KanMX6 vector (first the $3^{\prime}$ flanking region, followed by the $5^{\prime}$ flanking region), previously digested with the corresponding restriction enzymes (SacI and EcoRI to $3^{\prime}$ flanking region; NdeI and Bam $\mathrm{HI}$ to $5^{\prime}$ flanking region). The E. coli JM109 strain was transformed with the corresponding construction by chemical transformation (Sambrook and Russell, 2001; Froger and Hall, 2007) and five clones were analyzed by DNA sequencing to corroborate the correct incorporation of $7 \mathrm{xHis}$-tag. The final vector was named pFA6a-KanMX6-5'-3' and confirmed by DNA sequencing.

The synonymous substitutions were designed based on S. pombe codon usage (Forsburg, 1994; Hiraoka et al., 2009) replacing low-usage codons GGG/GGA (five codons) with their optimal counterpart GGT. Supplementary Table 1 shows the primers that were used. $C d c 13$ mutants were constructed according to the following methodology: first, the mutant $c d c 13$ sequence was amplified in five separate PCRs, using the following primers listed in Supplementary Table 1: cdc13-histag-F and CDC13_GGT1_R (reverse primer containing the first mutated codon) were used to amplify the first segment; CDC13_GGT1_F and CDC13_GGT2_R (reverse primer containing the second mutated codon) were used to amplify the second segment; CDC13_GGT2_F and CDC13_GGT3_R (reverse primer containing the third mutated codon) were used to amplify the third segment; CDC13_GGT3_F and CDC13_GGT45_R (reverse primer containing the last two mutated codons) were used to amplify the fourth segment; and CDC13_GGT45_F forward primer containing the last two mutated codons) and cdc13-histag-R were used to amplify the last segment. All PCR products were purified using the Real Genomics HiYieldTM Gel/PCR DNA fragments Extraction system commercial kit (Real Genomics) in accordance with the manufacturer's instructions, and then the purified PCR products were used as templates for four amplifications by PCR: segments I and II were used as templates to join both segments, amplifying with cdc13-histag-F and CDC13_GGT2_R primers. In another experiment, segments III and IV were used as templates to join both segments, amplifying with CDC13_GGT2_F and CDC13_GGT45_R primers (Supplementary Table 1). Both PCR products were purified the same way and were used as templates to join the four segments by amplified PCR with cdc13-histagF and CDC13_GGT45R primers (Supplementary Table 1). This product was joined with fragment $\mathrm{V}$ as described previously, amplified with cdc13 histag-F and cdc13-histag-R primer sets (Supplementary Table 1), resulting in the complete $c d c 13$ with the mutations. The final product was purified and digested with NdeI and BamHI restriction enzymes, and then ligated to the pFA6a-KanMX6-5'-3' vector. The product was transformed into the E. coli JM109 strain by chemical transformation (Sambrook and Russell, 2001; Froger and Hall, 2007) and 5 clones were analyzed by DNA sequencing to corroborate the correct incorporation of the mutations.

\section{Homologous Recombination}

Purified plasmids containing the flanking regions of the wildtype plus mutant coding sequences of $\mathrm{Cdc13}$ and the Histag were used to amplify the sequence used for homologous recombination (Oldenburg et al., 1997), using Herculase II Fusion DNA polymerase (Agilent Genomics) in accordance with the manufacturer's instructions, and using $\mathrm{pREP} 4 \mathrm{~F}^{\prime}$ and pREP41R' primers (Supplementary Table 1). $200 \mathrm{ng}$ of the corresponding PCR product and $300 \mathrm{ng}$ of the pET15b vector (as a carrier) were electroporated in $100 \mu \mathrm{l}$ of electrocompetent $S$. pombe cells were prepared with the described protocol (Forsburg and Rhind, 2006). Yeasts were washed with $1 \mathrm{M}$ sorbitol and recovered in YPD medium at $30^{\circ} \mathrm{C}$ for $3 \mathrm{~h}$. The cells were then pelleted, resuspended in $200 \mu \mathrm{l}$ of YE medium, and plated in YPD agar prepared with $200 \mu \mathrm{g} / \mathrm{ml}$ of G418 (geneticin) antibiotic (Sigma-Aldrich). Cells were grown for 45 days at $30^{\circ} \mathrm{C}$ and single colonies were picked and grown on YPD medium supplemented with $200 \mu \mathrm{g} / \mathrm{ml}$ of G418 antibiotic. The incorporation of synonymous mutations at the right position was corroborated by DNA sequencing.

\section{Overexpression of tRNAs}

Fragments containing tRNA genes (tRNA ${ }^{G l y}{ }_{U C C}$, tRNA ${ }^{G l y}{ }_{G C C}$, and tRNA ${ }^{A r g}{ }_{U C C}$ ) were amplified by PCR from S. pombe genomic DNA using Herculase II Fusion DNA polymerase (Agilent Genomics) in accordance with the manufacturer's instructions and using the primer set described in Supplementary Table 1. The PCR products contained 400 base pairs for tRNA ${ }^{G l y}$ UCC and 420 base pairs for tRNA ${ }^{G l y}{ }_{G C C}$ and tRNA ${ }^{A r g}{ }_{U C C}$, including the regulatory elements necessary for tRNA transcription. The products were purified using the commercial kit Real Genomics HiYieldTM Gel/PCR DNA Fragment Extraction (Real Genomics), in accordance with the manufacturer's instructions. The purified products were digested with BamHI and NdeI and cloned into pREP41, a high copy number vector. Vectors with tRNA genes were transformed into yeast by electroporation, as described previously (Forsburg and Rhind, 2006).

\section{Northern Blot Analyses}

Northern blot analysis was performed using biotinylated probes synthesized by IDT Technologies (Supplementary Table 2). 
Samples were transferred to positively charged nylon membranes for $2 \mathrm{~h}$ and $15 \mathrm{~min}$ at 20 volts in $0.5 \mathrm{X}$ TBE buffer $(45 \mathrm{mM}$ Tris-borate, $1 \mathrm{mM}$ EDTA). RNA was then fixed by UV radiation $(120,000 \mu$ joules) and membranes were blocked for $30 \mathrm{~min}$ at $41^{\circ} \mathrm{C}$ in pre-hybridization solution (6X SSC $(150 \mathrm{mM} \mathrm{NaCl}$, $15 \mathrm{mM}$ Sodium Citrate), 5X Denhardt's, 0.1\% SDS, $100 \mu \mathrm{g} / \mathrm{ml}$ salmon sperm DNA). After blocking, probes were added directly to the hybridization solution (6X SSC, $0.1 \%$ SDS, $100 \mu \mathrm{g} / \mathrm{ml}$ salmon sperm DNA) and incubated overnight. Membranes were incubated for $3 \mathrm{~min}$ at room temperature with solution $\mathrm{A}$ (2X SSC, $0.1 \%$ SDS) and then incubated twice for $15 \mathrm{~min}$ at $41^{\circ} \mathrm{C}$ in solution B (0.1X SCC, $0.1 \%$ SDS). Next, membranes were blocked for $30 \mathrm{~min}$ at room temperature with blocking solution ( $1 \%$ casein in maleic buffer; $0.1 \mathrm{M}$ maleic acid, $0.15 \mathrm{M}$ $\mathrm{NaCl} \mathrm{pH} \mathrm{7.5).} \mathrm{Then,} 0.1 \mu \mathrm{g} / \mathrm{ml}$ of streptavidin- horseradish peroxidase was added to the blocking solution. Membranes were incubated for $30 \mathrm{~min}$ at room temperature and then cleaned twice for 15 min with maleic acid buffer $0.3 \%$ (v/v) tween-20. Finally, membranes were cleaned for $3 \mathrm{~min}$ in predetection buffer (0.1 M Tris-HCl, 0.1 M NaCl, pH 9.5) and developed using a chemiluminescent kit [SuperSignal West Pico Chemiluminescent Substrate (Thermo Scientific)].

\section{Determination of tRNA Aminoacylation Levels in vivo}

Total RNA (obtained from the different strains that overexpress $\mathrm{tRNA}^{G l y}$ or $\mathrm{tRNA}^{A r g}$ ) was purified under acidic conditions and the $3^{\prime}$ extreme nucleotide was then eliminated by sodium periodate oxidation followed by $\beta$-elimination (Salazar et al., 2001; Choi et al., 2003). For this purpose, yeast was grown in EMM2 at $30^{\circ} \mathrm{C}$, until OD600 of $0.9-1.0$, and then pelleted at $10,000 \times g$ for $6 \mathrm{~min}$ at room temperature. The pellet was resuspended in $500 \mu \mathrm{l}$ of $0.3 \mathrm{M}$ sodium acetate at $\mathrm{pH} 5.2,1 \mathrm{mM}$ of EDTA, followed by the addition of $500 \mu \mathrm{l}$ of acid phenol. The mix was incubated for $10 \mathrm{~min}$ on ice and then centrifuged for $6 \mathrm{~min}$ at $10,000 \times g$. The supernatant was recovered, and RNA was precipitated adding three volumes of $100 \%$ ethanol at $-80^{\circ} \mathrm{C}$ overnight. Samples were centrifuged for $30 \mathrm{~min}$ at $14,000 \times g$ at $4^{\circ} \mathrm{C}$. Pellets were cleaned with $0.5 \mathrm{ml}$ of $75 \%$ ethanol, $10 \mathrm{mM}$ sodium acetate $\mathrm{pH} 5.2$ and then resuspended in $50 \mu \mathrm{l}$ of water. Each sample was divided into two tubes (A and B), each with $25 \mu \mathrm{l}$ aliquots. $1.42 \mu \mathrm{l}$ of $3 \mathrm{M}$ sodium acetate at $\mathrm{pH} 5.2$ was added to the A tubes, and then stored at $-80^{\circ} \mathrm{C}$. tRNA in the $\mathrm{B}$ tubes was deacylated by adding $6.25 \mu \mathrm{l}$ of $1 \mathrm{M}$ Tris acetate at $\mathrm{pH} 9.0$ and incubated for $60 \mathrm{~min}$ at $37^{\circ} \mathrm{C}$. Samples in the B tubes were precipitated by adding $3.13 \mu \mathrm{l}$ of $3 \mathrm{M}$ sodium acetate at $\mathrm{pH} 5.2$ and $62.5 \mu \mathrm{l}$ of ethanol at $100 \%$, and stored for $30 \mathrm{~min}$ at $-80^{\circ} \mathrm{C}$. Samples were centrifuged for $30 \mathrm{~min}$ at $13,000 \times g$ at $4^{\circ} \mathrm{C}$, pellets were washed with $70 \%$ ethanol and centrifuged at $13,000 \times g$ for $5 \mathrm{~min}$ at $4^{\circ} \mathrm{C}$. The pellet was dried and resuspended in $26.4 \mu \mathrm{l}$ of $160 \mathrm{mM}$ sodium acetate $\mathrm{pH}$ 5.2. Samples from the A tubes were thawed and $4.8 \mu \mathrm{l}$ of freshly prepared $250 \mathrm{mM}$ sodium periodate was added to each sample. Tubes were covered in aluminum paper and incubated for $90 \mathrm{~min}$ on ice, and then $12.97 \mu \mathrm{l}$ of $20 \%$ glucose was added. After an additional $90 \mathrm{~min}$ of incubation on ice, $4.3 \mu \mathrm{l}$ of $3 \mathrm{M}$ sodium acetate at $\mathrm{pH} 5.2$ and $87 \mu \mathrm{l}$ of ethanol were added. Samples were stored for at least $30 \mathrm{~min}$ at $-80^{\circ} \mathrm{C}$ and centrifuged for $30 \mathrm{~min}$ at $13,000 \times g$ at $4^{\circ} \mathrm{C}$. Pellets were resuspended in $250 \mu \mathrm{l}$ of $0.5 \mathrm{M}$ lysine at $\mathrm{pH} 8.0$ and incubated for $60 \mathrm{~min}$ at $45^{\circ} \mathrm{C}$. Then, $25 \mu \mathrm{l}$ of $3 \mathrm{M}$ sodium acetate at $\mathrm{pH} 5.2$ and $500 \mu \mathrm{l}$ of ethanol were added and samples were stored for at least $30 \mathrm{~min}$ at $-80^{\circ} \mathrm{C}$. Tubes were centrifuged again for $30 \mathrm{~min}$ at $13,000 \times g$ at $4^{\circ} \mathrm{C}$ and then washed with $70 \%$ ethanol. Finally, pellets were dried and resuspended in $15 \mu$ l of RNAse-free water. Samples were analyzed by gel electrophoresis ( $8 \mathrm{M}$ urea, $10 \%$ polyacrylamide), followed by Northern blot analysis.

\section{mRNA Isolation and Quantification}

To quantify $c d c 13$ mRNA, wild-type and over-expressed tRNA strains were grown to the late exponential phase (A600, 1.0) in $15 \mathrm{ml}$ of EMM2 medium under standard conditions. Yeasts were then pelleted at 2,250 $\times g$ for $5 \mathrm{~min}$ at room temperature and washed once with sterilized water. Cell walls were disrupted with $0.12 \mu \mathrm{g}$ of zymolyase $20 \mathrm{~T}$ (United States Biological) in $1 \mathrm{M}$ of sorbitol for $30 \mathrm{~min}$ at $37^{\circ} \mathrm{C}$. Cells were pelleted and resuspended in $200 \mu \mathrm{l}$ of TRIzol (Thermo Scientific) and vortexed three times for $1 \mathrm{~min}$ each (intercalated with $1 \mathrm{~min}$ on ice). Then, $40 \mu \mathrm{l}$ of chloroform was added to the mix and immediately centrifuged at $12,000 \times g$ for $20 \mathrm{~min}$ at $4^{\circ} \mathrm{C}$. The supernatant was precipitated with 0.7 volumes of isopropanol at $-80^{\circ} \mathrm{C}$ overnight. RNA was pelleted at $15,000 \times g$ for $30 \mathrm{~min}$ and washed once with $80 \%$ ethanol. RNA was resuspended in $30 \mu \mathrm{l}$ of sterilized miliQ water and quantified in a nanodrop spectrometer (BioTek), and then visualized in a $1 \%$ agarose gel to check RNA integrity. $1 \mu \mathrm{g}$ of RNA was treated with DNAse I (Roche), according to the instructions provided in the manual. $500 \mathrm{ng}$ of RNA was used for cDNA synthesis followed by Real-Time PCR with Brilliant II QRT-PCR, AffinityScript Two-Step Master Mix (Agilent), according to the manufacturer's instructions. The primers used in the Real-Time PCR are listed in Supplementary Table 1 (cdc13rtF and cdc13rtR primers). Actin was used as a control in the quantifications.

\section{Cell-Cycle Synchronization by Hydroxyurea}

Hydroxyurea (HU) was used to synchronize cells in the earlymid S phase, as described previously (Luche and Forsburg, 2009). Cells were grown in $5 \mathrm{ml}$ of EMM2 at $30^{\circ} \mathrm{C}$ overnight, with constant agitation. Subsequently, the saturated culture was brought to an OD600 of 0.1 and incubated for $3 \mathrm{~h}$ or until an OD600 0.2-0.6 HU was added at a final concentration of $15 \mathrm{mM}$ and incubated for $4 \mathrm{~h}$ at $30^{\circ} \mathrm{C}$ with constant agitation. After the time, cells were collected by centrifuging at $4,000 \times g$ for $5 \mathrm{~min}$ at room temperature. The supernatant was discarded, and the resulting sediment was washed twice with half the volume used of EMM2, previously incubated at $30^{\circ} \mathrm{C}$, to remove residual HU. The sediment was resuspended in $1 \mathrm{ml}$ of sterile EMM2 and incubated at $30^{\circ} \mathrm{C}$ with constant agitation, during all the experiment time $(24 \mathrm{~h})$ and a $10 \mu \mathrm{l}$ aliquot was taken every $3 \mathrm{~h}$. The phenotype was analyzed observing the cells by optical microscopy. A 40X objective (total magnification: 400) was used. 
The photos were obtained using a camera attached to a Canon SLR model Eos Rebel T3 lens microscopy.

\section{Total and Aggregated Protein Isolation and Quantification}

Wild-type and mutant strains were grown at the exponential phase $(\mathrm{OD} 600,1.0)$ in $20 \mathrm{ml}$ of EMM2 medium at $30^{\circ} \mathrm{C}$ with constant agitation. Yeasts were harvested by centrifugation at $2,250 \times g$ for $5 \mathrm{~min}$ at room temperature, and the pellet was used to analyze protein aggregation as described previously (Rand and Grant, 2006). Briefly, cells were pelleted and resuspended in lysis buffer [50 mM potassium phosphate buffer, $\mathrm{pH}$ 7, $1 \mathrm{mM}$ EDTA, 5\% glycerol, $1 \mathrm{mM}$ of phenylmethylsulfonyl fluoride, and Complete Mini protease inhibitor cocktail (Roche)]. Cell disruption was carried out by three vortex cycles ( 1 min of vortex and $1 \mathrm{~min}$ on ice) with $220 \mathrm{mg}$ of acid-washed glass beads (Sigma-Aldrich G8772). Membrane proteins were removed by washing twice with $320 \mu \mathrm{l}$ lysis buffer and $80 \mu \mathrm{l}$ of $10 \% \mathrm{NP}$ 40 (Sigma-Aldrich), and the final aggregated protein extract was resuspended in $20 \mu \mathrm{l}$ of $1 \mathrm{X}$ Laemmli sample buffer. Total and aggregated protein extracts were analyzed by Western blot using an anti His-tag antibody in a 1:1,000 dilution (His Tag Antibody MAB050R-100, R\&D Systems). Western blot against tubulin was performed as an internal control (T5168 monoclonal anti-atubulin clone B-5-1-2, Sigma-Aldrich). Bands representing WT, the pREP41_tRNA strain, and tubulin (for total protein), or WT and pREP41_tRNA strain (for aggregated proteins) were quantified using ImageJ software.

\section{Statistical Significance}

The results are presented as mean \pm standard deviations of the number of independent experiments indicated (biological replicates) (n) or as a representative example of experiments performed at least three times independently. Data were analyzed statistically using GraphPad Prism 6.0 software. The results were analyzed using the unpaired $t$-student test to determine significant differences among the experimental conditions. A $p$ value $<0.05$ was considered the limit of significance.

\section{RESULTS}

\section{Replacement of Rare Glycine Codons for Synonymous Preferred Codons in cdc13 Severely Affects S. pombe Growth}

We used the gene encoding $\mathrm{Cdc13}$, which is rich in nonoptimal glycine codons to evaluate the effect of replacing nonoptimal for optimal codons. GGA and GGG glycine codons are highly represented in $c d c 13$ (5 of the 13 glycine codons, $38.4 \%$ compared to less than $1 \%$ in highly-expressed genes) (Supplementary Table 3). Thus, we choose to replace these rare codons with the optimal GGT codon (86\% of the glycine codons in highly-expressed genes) (Figure $\mathbf{1}$ and Supplementary Table 3), as described above. Surprisingly, the replacement of GGA/GGG codons with GGT in $c d c 13$, yielded two types of colonies, small (most of them) and large (the remaining few)
(Supplementary Figure 1, upper panel). The small colonies did not grow on either solid orin liquid media. The large colonies were cultured in liquid medium, where they grew slowly. Cell shape was observed by light microscopy at $16 \mathrm{~h}$ of culturing in rich medium. The mutant cells presented a phenotype similar to that of wild-type strains, although some cells were elongated, similar to what has been observed in yeast where the cell cycle is blocked after the G2 phase (Oltra et al., 2004; Supplementary Figure 1, lower panel). We believe that the replacement of rare glycine codons by optimal synonymous codons produced an altered $\mathrm{Cdc} 13$ protein that is non-functional to the cells, consequently cells stopped proliferating after a few duplications. Inspection of the $c d c 13$ sequence around the replaced codons did not reveal any alteration of off-frame stop codons (ambush hypothesis) (Seligmann and Pollock, 2004) that might account for the growth defect. However, large colonies proliferate even though $c d c 13$ contains all the rare glycine codon replacements (confirmed by DNA sequencing). The effect of replacing $c d c 13$ with mutated genes should be investigated, as should the differences in growth between the large and small colonies.

\section{tRNA ${ }^{\text {Gly }}$ ucc Overexpression Does Not Affect the Level of Other tRNA Gly}

As noted above, tRNA levels in S. cerevisiae vary during the cell cycle, with the maximum at G2-M transition (FrenkelMorgenstern et al., 2012). Since the replacement of rare glycine codons by optimal synonymous codons had a dramatic effect on S. pombe proliferation, we thought that the translation of rare codons may be controlled by the concentration of the decoding tRNA. The rare glycine codons GGA and GGG in S. pombe are decoded by the tRNA ${ }^{G l y} U C C$, encoded by three almost identical genes (low copy number compared to other tRNA ${ }^{G l y}$ genes). The tRNA ${ }^{G l y} C C C$ encoded by a single copy of the gene also decodes GGG codons (Supplementary Table 3).

We determined whether the expression of tRNA ${ }^{G l y}$ UCC is regulated in wild-type cells (as in S. cerevisiae) (Pang et al., 2014) by treating the cells with hydrogen peroxide and measuring the level of this tRNA. S. pombe cells were exposed to 5 or $10 \mathrm{mM}$ of hydrogen peroxide and catalase activity was measured to confirm the response of the cells to oxidative stress. Increased catalase activity was observed under both conditions (data not shown). At $10 \mathrm{mM}$ of hydrogen peroxide, the level of tRNA ${ }^{G l y} U C C$ increased fivefold, indicating that the level of tRNA ${ }^{G l y} U C C$ is regulated in response to this external challenge (Supplementary Figure 2A).

To test whether an increase in tRNA ${ }^{G l y}$ UCC concentration affects the level of Cdc13, we overexpressed this tRNA in S. pombe. For this purpose, we cloned the corresponding tRNA gene (which contains an internal RNA polymerase III promoter) in the high copy number vector pREP41, with LEU2 as selection marker. S. pombe cells were transformed with this construct (Supplementary Figure 2B), with the empty vector as a control. Northern blot analysis using a specific probe for tRNA ${ }^{G l y}$ UCC revealed a 7-to-8-fold increase in the level of this tRNA compared to the control (Figure 2A). The overexpression of tRNA ${ }^{\text {Gly }} U C C$ did not affect the levels of other tRNA ${ }^{\text {Gly }}$ (tRNA ${ }^{G l y}{ }_{G C C}$, tRNA ${ }^{\text {Gly }}$ CCC) (Figure 2A). We also tested the aminoacylation status of 
A ATG ACt ACC CGT CGT TTA ACT CGC CAG CAC CTA TTG GCA AAT ACC TTG GGC AAC AAT GAC GAA AAT CAT CCT TCA AAC CAT ATT GCC CGT GCA AAA AGC TCT TTG CAC TCT TCA GAA AAT TCT TTA GTA AAT GGC AAG AAA GCC ACT GTG TCT TCC ACC AAC GTT CCT AAG AAG CGT CAT GCG TTG GAT GAT GTT TCC AAT TTT CAC AAC AAA GAA GGT GTT CCA TTA GCT AGT AAA AAC ACA AAT GTC AGA CAC ACT ACT GCT TCT GIC AGT ACC CGT CGT GCT CTC GAG GAA AAG TCT ATA ATC CCT GCA ACA GAT GAT GAA CCC GCT ICC AAG AAG CGT CGC CAA CCI TCT GIT ITT AAT TCA ICA GIC CCC ICG ITA CCT CAA CAC ITG TCA ACG AAA TCA CAC TCT GIT ICA ACC CAT GGG GTT GAT GCT TTC CAT AAG GAT CAA GCA ACT ATT CCA AAA AAA TTA AAG AAA GAT GTT GAT GAA CGC GTT GTI TCG AAA GAT ATT CCC AAA CTI CAC CGT GAT AGT GTT GAG AGT CCC GAA ICT CAA GAT TGG GAT GAC TTG GAT GCA GAA GAT TGG GCT GAC CCT CTT ATG GIT TCT GAA TAT GIC GIT GAT ATT TTT GAA TAT TIG AAT GAG ITG GAA ATT GAA ACT ATG CCC TCT CCT ACT TAT ATG GAT CGT CAA AAA GAG CTT GCA TGG AAG ATG CGI GGA ATA CTT ACC GAT IGG TTA ATT GAA GTG CAT TCT CGT TIC CGA CTG CTI CCT GAA ACA TTG TTT TTG GCC GTA AAT ATT ATT GAT AGA TTT TTA TCA TTG CGG GTA TGC TCT CTT AAC AAA CTA CAA TTG GTT GGC ATT GCT GCC TTG TTC ATC GCT AGC AAG TAT GAG GAG GTG ATG TGC CCT TCA GTC CAA AAC TTT GTA TAT ATG GCG GAT GGT GGG TAT GAT GAA GAG GAA ATT CTT CAA GCC GAG CGC TAC ATT TIG CGT GTC CTA GAG TTT AAT CTT GCT TAC CCG AAT CCT ATG AAT TTC CTA CGT CGT ATC TCA AAA GCC GAC TTI TAC GAT ATT CAA ACA AGA ACT GIT GCA AAG TAT CTT GTT GAA ATT GGT CTT TTA GAT CAT AAA CTT TTA CCT TAT CCC CCT TCC CAA CAG TGI GCT GCC GCT ATG TAC CTT GCC AGG GAA ATG CTT GGA CGI GGA CCG TGG AAT CGT AAT CTT GTG CAT TAC TCA GGT TAT GAG GAG TAC CAA TTA ATT TCC GTT GTT AAG AAG ATG ATT AAT TAT TTA CAA AAG CCT GTT CAA CAT GAA GCT TTT TTC AAG AAG TAT GCC TCC AAA AAG TTT ATG AAA GCT AGT CTT TTT GTT CGT GAC TGG ATC AAG AAG AAT TCT ATC CCT CTT GGC GAT GAC GCT GAT GAA GAT TAT ACT ITT CAC AAG CAA AAA CGT ATA CAA CAT GAC ATG AAA GAT GAA GAA TGG TAA

B

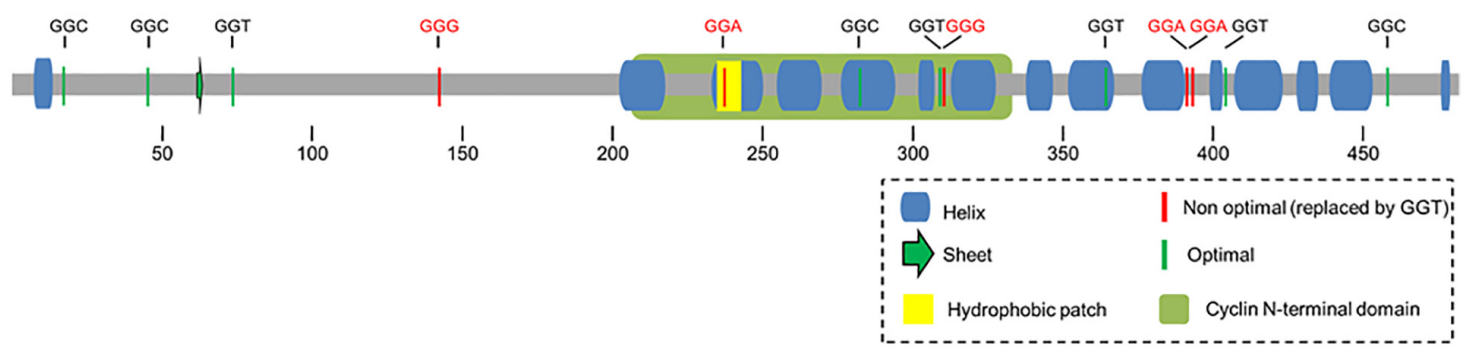

FIGURE 1 | (A) Sequence of cdc13 and localization of Gly codons. The coding sequence of cdc13 is shown and unreplaced Gly codons (green boxes) and replaced codons (pink boxes) are indicated. (B) Schematic representation of secondary structure of Cdc13 from S. pombe. Location of glycine codons in the secondary structure of Cdc13 and the corresponding optimal (green) and non-optimal (red) codons in mRNA. The yellow square represents the hydrophobic motif MRGILTDW and the green rectangle represents the cyclin domain.

these tRNA Gly with overexpression of tRNA ${ }^{G l y}$ UCC. The ratio of aminoacylated/deacylated tRNA in cells transformed with the empty vector and cells that overexpressed tRNA ${ }^{G l y}$ UCC was determined. We observed a $\sim 20 \%$ increase in the amino acylated fraction of tRNA ${ }^{G l y}$ UCC compared to the control (Figures 2B,C) (although it was not a statistically significant) The fact that the level of this tRNA increased 7-to-8-fold in cells transformed with the vector containing the tRNA ${ }^{G l y}$ UCC gene (Figure 2A) implies that the amount of Gly-tRNA ${ }^{\text {Gly }}$ increases 10-to-11fold compared to the control. However, the overexpression of tRNA $^{G l y}$ UCC did not significantly change the amino acylation levels of other tested tRNA ${ }^{\text {Gly }}$ isoacceptors (Figures 2B,C).

\section{Overexpression of tRNA ${ }^{\text {Gly }}$ ucc Affects the Distribution of Cdc13 Into Soluble and Aggregated Fractions}

We used cells transformed with pREP4-tRNA ${ }^{G l y} U C C$ and control cells to evaluate the effect of tRNA ${ }^{\text {Gly }}$ UCC overexpression on $\mathrm{Cdc13}$ expression. Neither total Cdc13 protein levels (Figures 3A-C) nor its mRNA levels (Figure 3D) were altered by tRNA ${ }^{G l y}$ UCC overexpression. However, when the soluble and aggregated fractions were separated, a dramatic increase in Cdc13 was observed in the aggregated fraction (Figure 3A, quantified in Figure 3B). Together, these results suggest that increasing tRNA $^{G l y}{ }_{U C C}$ levels increases the Cdc13 in the aggregated fraction without affecting its level. Further investigation is needed to determine if this is the result of Cdc13 misfolding because of a change in the mRNA translation rate. An alternative explanation for this defect is that other proteins (including chaperones) are altered by tRNA ${ }^{G l y}{ }_{U C C}$ overexpression and aggregate with Cdc13. Another explanation is that tRNA ${ }^{G l y}$ UCC overexpression causes increased mismatches with non-cognate codons that are not compensated (Seligmann, 2011), giving rise to translation errors that induce protein aggregations. These and other alternative explanation need to be investigated.

\section{Overexpression of tRNA ${ }^{\text {Gly }}$ ucc Affects the Progression of the $S$. pombe Cell Cycle}

To test whether the overexpression of tRNA ${ }^{\text {Gly }}$ affects the cell cycle progression of $S$. pombe, yeast cultures were synchronized with HU. The shapes of cells that overexpress $\mathrm{tRNA}^{G l y}{ }_{U C C}$ 

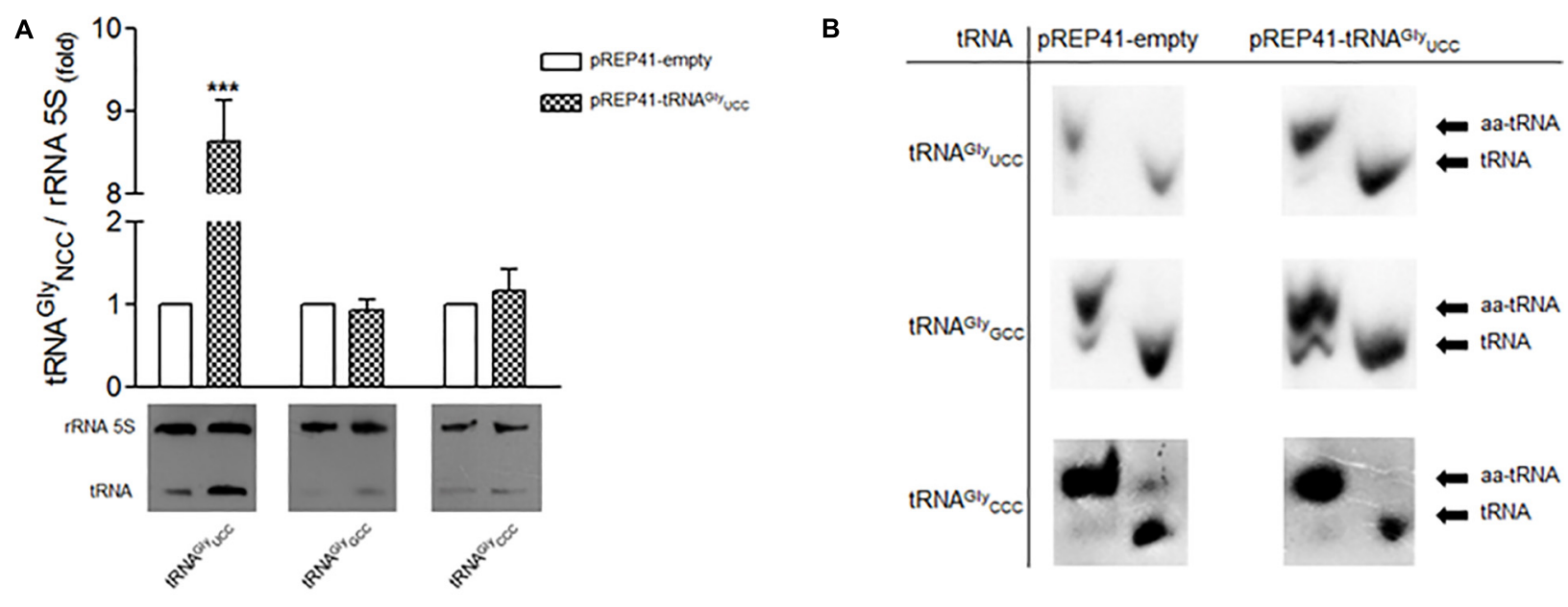

c

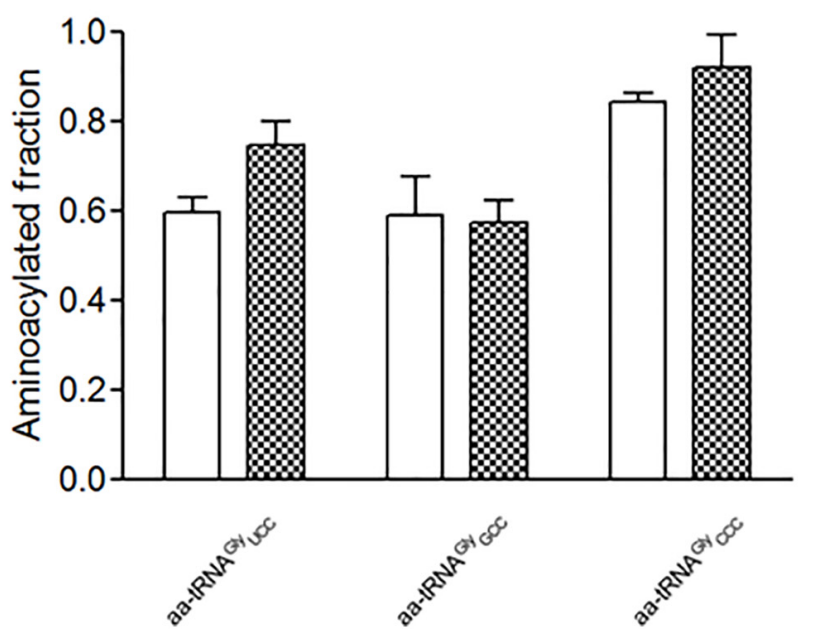

FIGURE 2 | Overexpression of tRNA ${ }^{\text {GIy }}$ UCC (low gene dosage) and the effect on the level and aminoacylation of tRNA ${ }^{\text {Gly }}$ isoaceptors. (A) Lower panel. Northern blot of tRNA Gly $U C C$, tRNA ${ }^{G / y}$ GCC and tRNA Gly $C C C$ after overexpression of tRNA $A^{G l y}$ UCC. Upper panel, relative levels of tRNA ${ }^{G l y}$ isoacceptors in cells that overexpress tRNA Gly UCC. 5S rRNA was used as a reference (folds of change (*** $p<0,001, t$-student). (B) Aminoacylation of tRNA Gly isoacceptors. Representative Northern blot analysis of total tRNA purified under acidic conditions from S. pombe transformed with pREP41-empty (control) or pREP41-tRNA ${ }^{\text {Gly }}$ UCC, detected with specific probes against tRNA ${ }^{G l y}$ UCC, $_{\text {, } R N A}{ }^{\text {Gly }}{ }_{\text {GCC }}$, and tRNA ${ }^{\text {Gly }}$ CCC. Aminoacylated tRNAs (aa-tRNA) and non-aminoacylated tRNAs (tRNA) are indicated. (C) Quantification of Northern blots. Relative levels of aminoacylated fraction of tRNA ${ }^{G / y}$ UCC, tRNA ${ }^{G l y}$ GCC, and tRNA ${ }^{G l y}$ CCC for each condition, were quantified by densitometric analysis.

and control cells were monitored under a microscope at $12 \mathrm{~h}$ (three cell cycles). Under these conditions, we observed that nearly $100 \%$ of cells that overexpress tRNA ${ }^{\text {Gly }}$ UCC had elongated shapes (Figure 4A). The average size of cells that overexpress tRNA $^{\text {Gly }}$ UCC was at least twice that of the control cells, but some were four times as large (Figure 4B). More than one septum was observed microscopically in the elongated cells. Unsynchronized cells also evidenced elongated shape, but to a lesser extent.

In order to evaluate whether the elongated phenotype is a specific result of the overexpression of $\operatorname{tRNA}^{G l y}{ }_{U C C}$ and not the overexpression of any other tRNA ${ }^{G l y}$, we overexpressed the high copy number tRNA ${ }^{G l y}$ GCC gene in $S$. pombe that decodes both optimal glycine codons. We observed a twofold increase in tRNA $^{G l y}{ }_{G C C}$ (Figure 5A). As tRNA ${ }^{G l y}{ }_{G C C}$ is encoded by eight copies (Supplementary Table 3 ), we expected relatively high levels of this tRNA in the cells. However, $S$. pombe showed no elongated phenotypes (Figure 5B). Similar experiments involved overexpressing tRNA ${ }^{A r g}{ }_{U C U}$. This tRNA decodes the arginine AGA (preferred) and AGG (rare) codons present in S. pombe $c d c 13$. The tRNA gene was cloned as indicated for tRNA ${ }^{G l y}{ }_{U C C}$. A 2.5-fold increase in the cellular level of tRNA was observed (data not shown). However, the overexpression of $\mathrm{tRNA}^{\mathrm{Arg}} \mathrm{UCU}$ did not alter cell shape, as tRNA ${ }^{G l y} U C C$ overexpression did (data not shown).

\section{DISCUSSION}

Translation efficiency and accuracy are largely achieved by binding to the ribosome of the proper aminoacyl-tRNA that 


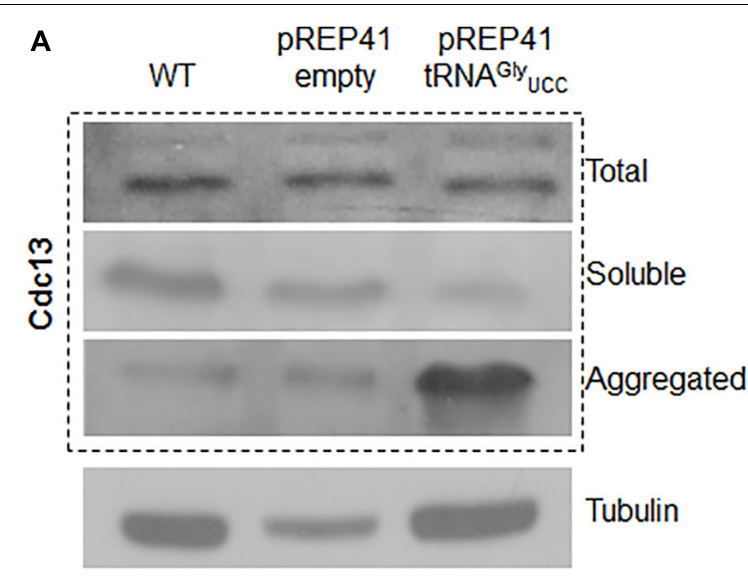

C

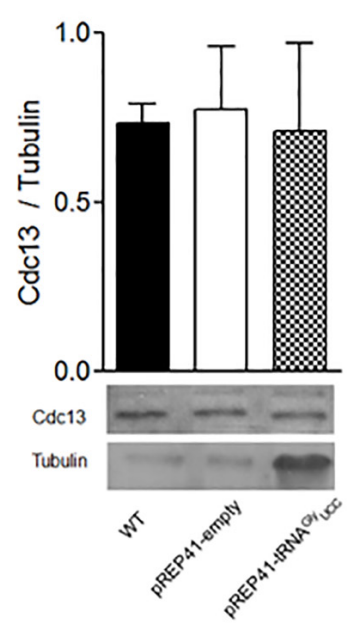

B

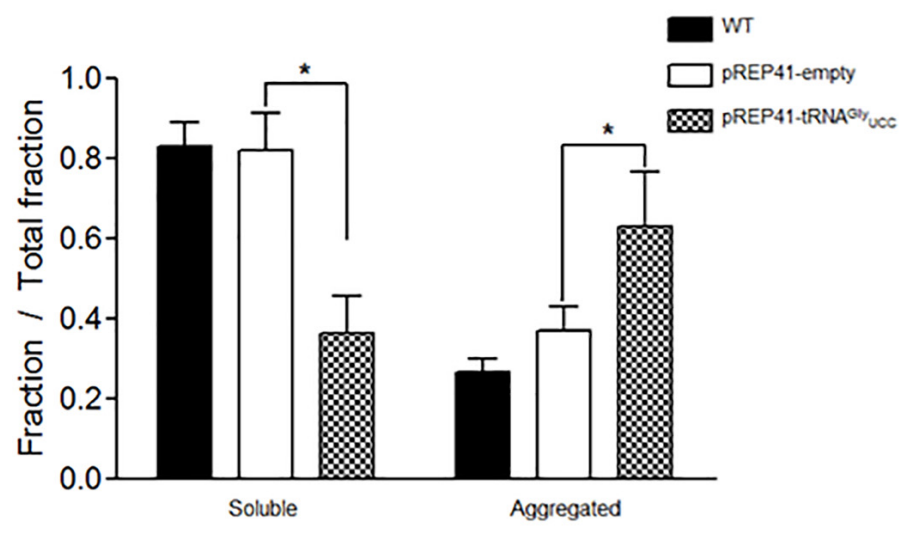

D

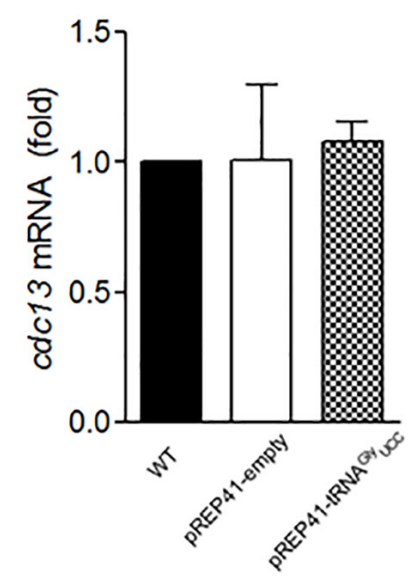

FIGURE 3 | Overexpression of tRNA Gly UCC in S. pombe affects the aggregation status of Cdc13. (A) Western blot of Cdc13 in total extract or soluble and aggregated fractions. (B) Quantification of soluble and aggregated Cdc13 compared to total extract. (C) Total Cdc13 in cells that overexpress tRNA ${ }^{\text {Gly }}$ UCC compared to controls. (D) Relative levels of cdc13 mRNA compared to those of controls (pREP41-empty). ( ${ }^{*} p<0.05, t$-student).

competes with a plethora of non-cognate or near-cognate aminoacyl-tRNAs (all at different concentrations) to enter the A site, Ikemura (1985), Kanaya et al. (1999), Frenkel-Morgenstern et al. (2012), Kirchner et al. (2017), Torrent et al. (2018), Yang et al. (2020). This gives rise to the notion that optimal codons are translated by highly represented transfer RNAs. The translation speed of certain codons has been explained as the result of the time required by the ribosome to find the proper aminoacyl-tRNA to translate the codon in the A site. Rare codons are usually translated by lowly-represented tRNAs. The ribosome must deal with stochastic binding of these tRNAs in competition with the entire pool of highly represented tRNAs, which slows down the translation of rare codons. There are a few examples where the level of transfer RNAs alters or regulates the translation of genes crucial for cellular processes based on the presence of non-optimal codons, in particular mRNAs. A mutation that replaces an optimal codon by a rare synonymous codon in human CFTR gene lead to a misfolded and malfunctioning proteins. An increase in the level of tRNA decoding such a codon restores the function of CFTR (Kirchner et al., 2017). In yeast, stress-responsive genes are enriched in codons that use rare tRNAs. The tRNAs of cells exposed to different stresses are reprogrammed to respond to stress by enhancing stress mRNA translation (Torrent et al., 2018). Certain tRNAs are preferentially expressed in human cancer cells under the control of an RNA polymerase III transcription factor. The knockdown of these tRNAs reduces the proliferation of cancer cells, which indicates their crucial role in the reprogramming cell proliferation (Yang et al., 2020).

The cell cycle is a complex process that requires the temporal expression of a number of proteins that regulate the functioning of the different phases of the process in coordination. The fission yeast $S$. pombe has been a model to study the cell cycle of eukaryotes (Yanagida, 2002). Many of the cell cycle proteins from $S$. pombe are temporarily expressed based on the transcription and translation of corresponding genes, as well as the degradation of gene products in a well-coordinated process (Hayles et al., 2013). Several of these proteins are enriched in rare codons, 


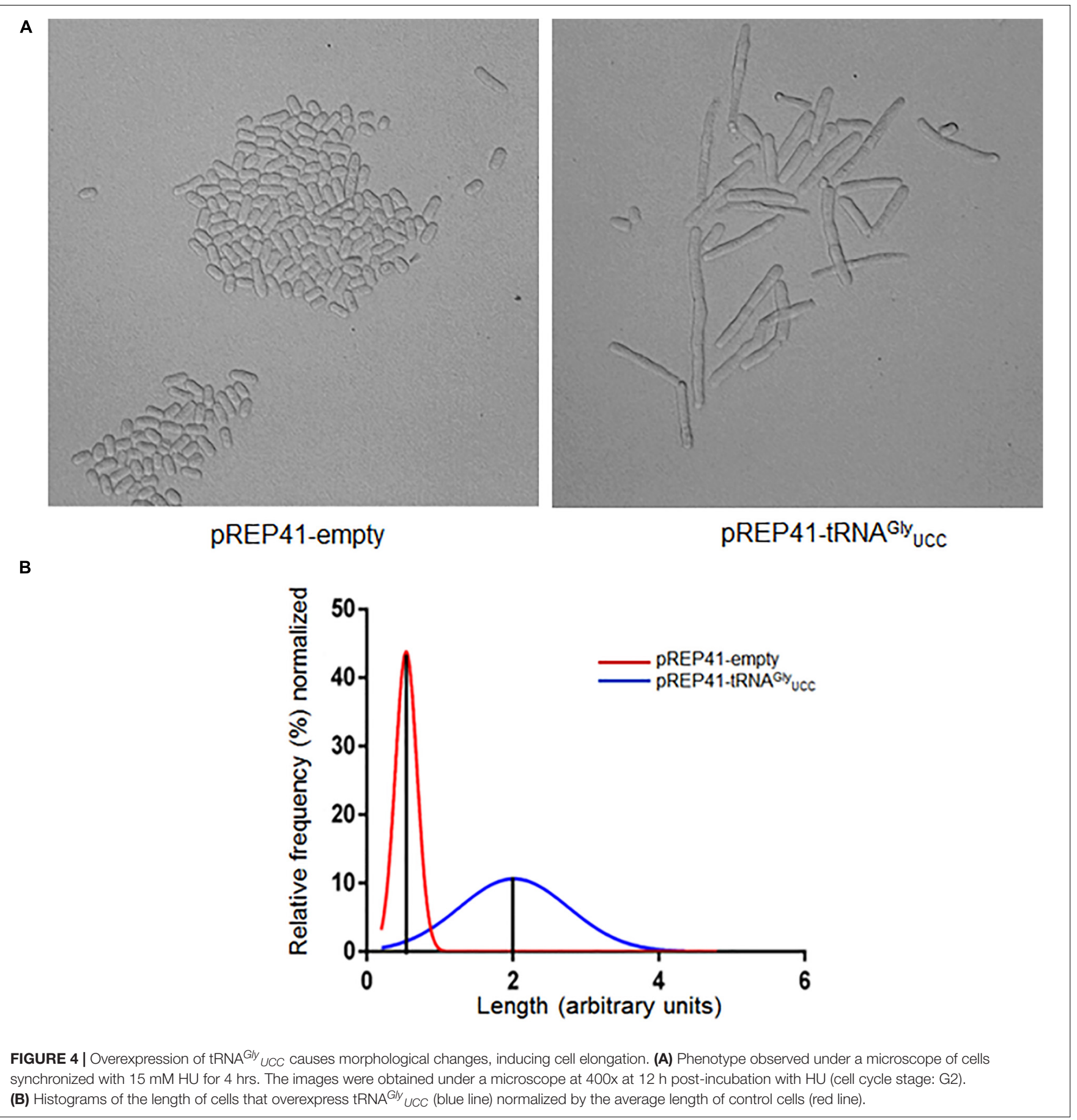

giving rise to the notion that translation efficiency is in part a way to control the level of some proteins. The levels of transfer RNAs oscillate markedly, with increases in the G2 phase, concomitant with an increase in the activity of several amino acyl tRNA synthetases, including GlyRS (Frenkel-Morgenstern et al., 2012). The two molecular events match with the expression patterns of certain cyclins. These observations reinforce the idea that translation of these proteins is regulated cyclically by tRNA levels.
Cdc13 is a crucial protein that controls the G2-M transition of the $S$. pombe cell cycle. The presence of five non-optimal codons of the thirteen codons for glycine in $c d c 13$ suggests that the level of this protein is controlled at the translational level. The data obtained in this work reveals that alterations of rare codons decoding glycine in the gene that encodes Cdc13 have a profound impact on cell proliferation. First, the replacement of all five codons by optimal counterparts, where 2 of the 5 rare glycine 


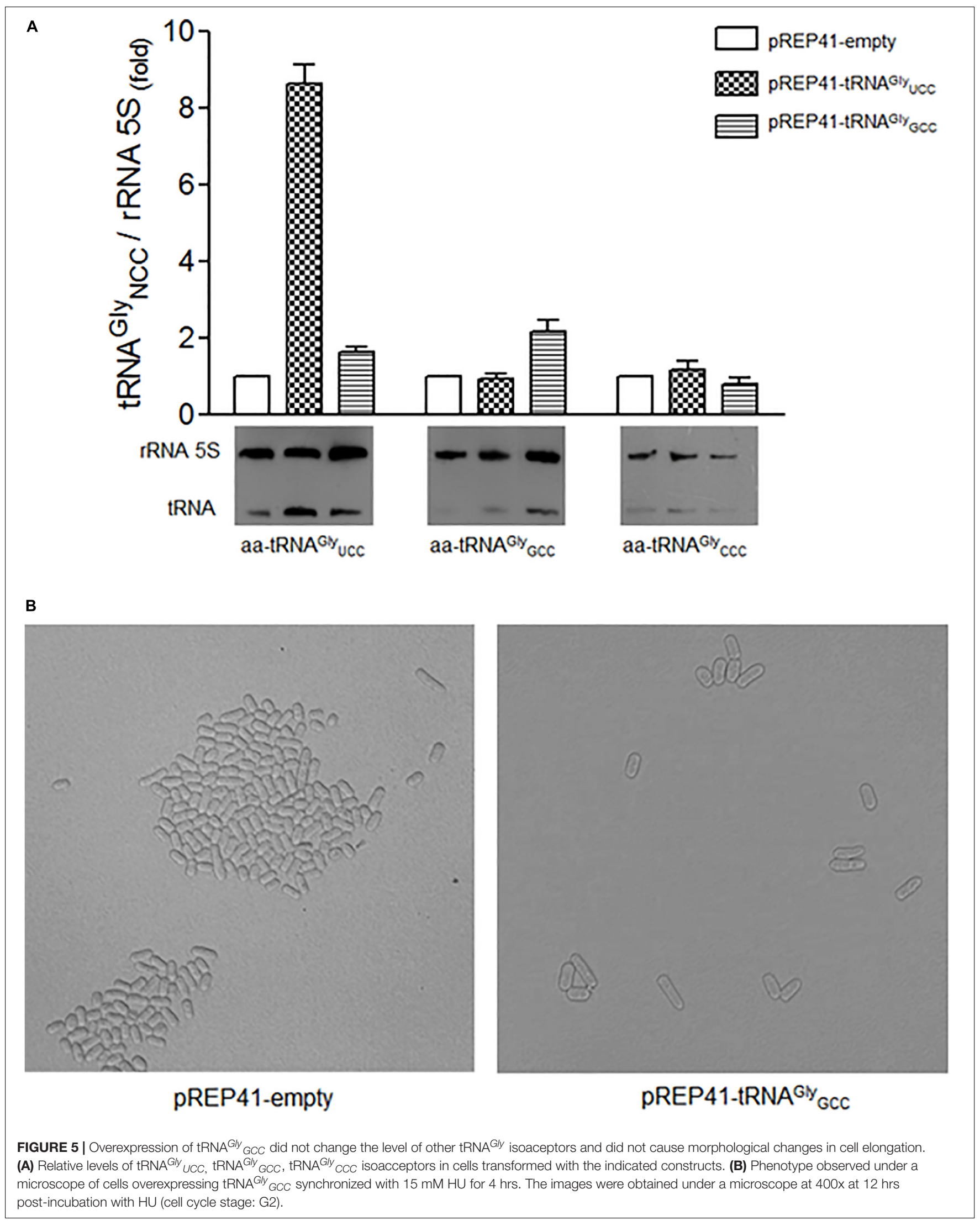


codons are in the cyclin N-terminal domain (Figure 1), and the other two are located in tandem near the C-terminus, results in the almost complete impairment of the cells to proliferate in solid or liquid media (Supplementary Figure 1). It is believed that synonymous codons tend to be translated more slowly than optimal counterparts (Shah and Gilchrist, 2011; Boël et al., 2016) suggesting an alteration of co-translational protein folding. Other reports suggest that protein synthesis is under selective evolutionary pressure by co-translational folding (Chaney et al., 2017; Jacobs and Shakhnovich, 2017). One hypothesis is that subtle modifications in the elongation rate affect the folding mechanism (Braselmann et al., 2013), although cells have molecular chaperones that help in folding proteins adequately, including folding nascent polypeptides (Kramer et al., 2019). According to our results it is possible that the replacement of rare glycine codons by optimal counterparts results in misfolded Cdc13, as has been suggested (Zhou et al., 2015), This would reduce the levels of functional $\mathrm{Cdc13}$, although there may be other interpretations of the results (see below).

Studies have shown that a complex between Cdc2 (Cdk1) and Cdc13 is required for the cells in $S$. pombe to enter mitosis. It has been reported that the deletion of the $c d c 13$ gene gives rise to small cells that do not enter mitosis, although some of them can continuously replicate, giving rise to elongated cells with giant nuclei (Hayles et al., 1994). Patterson et al. (2019) described another example of elongated cells and demonstrated that Cdc13 expression below wild-type levels results in larger cells. They found a correlation between Cdc13 expression levels and cell size at division. Using mutant cells with a thermosensitive mutation in $c d c 13$, they found that at the restrictive temperature, the complex was largely in the insoluble fraction, which prevents the cell from entering mitosis (Hayles et al., 1994). Our results show that overexpression of tRNA ${ }^{G l y}{ }_{U C C}$ is accompanied by a substantial increase in $\mathrm{Cdc13}$ in the aggregated protein fraction (up to $50 \%$ of the all $\mathrm{Cdc13}$ proteins, Figure 3), along with the formation of elongated cells (Figure 4). The effects observed in our work may be the result of several different events, such as aggregation of other proteins that drag Cdc13, impairment of chaperones to properly fold $\mathrm{Cdc13}$, or effects on other cyclins. However, the observed effects are consistent with the role of Cdc13 in forming the complex described above (Hayles et al., 1994; Humaidan et al., 2018) and the cell replication problem as a consequence of replacing rare Gly codons in $c d c 13$. Further experiments are required to confirm whether there is a direct effect on Cdc13 folding and aggregation that alters the cell cycle. Nevertheless, these two effects seem to be specific to tRNA ${ }^{\text {Gly }}$ UCC, as they are not observed when the tRNAs that decode optimal glycine or arginine codons are overexpressed.

The overexpression of Gly-tRNA ${ }^{G l y}$ UCC probably exerts an effect on not only $c d c 13$ mRNA, but also many other mRNAs

\section{REFERENCES}

Arquès, D. G., and Michel, C. J. (1996). A complementary circular code in the protein coding genes. J. Theor. Biol. 182, 45-58. doi: 10.1006/jtbi.1996. 0142 containing the decoded codons. Thus, the observed cell division phenotype maybe the consequence of the altered expression of other genes involved in the cell cycle. Analysis of the effect of global proteome alterations on tRNA ${ }^{G l y}$ UUC overexpression, or the overexpression of any other tRNAs will certainly give insights into the role of rare codons in the cell cycle, as well as the selective pressure that allows the natural selection of rare codons in cell cycle proteins.

\section{DATA AVAILABILITY STATEMENT}

The original contributions presented in the study are included in the article/Supplementary Material, further inquiries can be directed to the corresponding author/s.

\section{AUTHOR CONTRIBUTIONS}

LA conducted most of the experiments as part of her Magister thesis. FM, DG, and RF-R contributed with part of the experimental data. MT conducted all bioinformatic analysis. SM supervised the thesis of LA and contributed with her expertise on $S$. pombe manipulation. AK contributed with ongoing discussion and reviewing the manuscript. OO provided the funds, conceptual questions, ongoing discussion and training of students. All authors contributed to the article and approved the submitted version.

\section{FUNDING}

This work was supported by Fondecyt, Chile by grants 1150834 and 1190552 to OO, 1191074 to AK, and 3150366 to SM. LA was recipient of the Conicyt, Chile fellowship for graduate studies.

\section{ACKNOWLEDGMENTS}

We thank Fondecyt, Chile for financial support and the Universidad de Chile and Universidad de Santiago for logistical support.

\section{SUPPLEMENTARY MATERIAL}

The Supplementary Material for this article can be found online at: https://www.frontiersin.org/articles/10.3389/fmicb. 2020.607693/full\#supplementary-material

Bali, V., and Bebok, Z. (2015). Decoding mechanisms by which silent codon changes influence protein biogenesis and function. Int. J. Biochem. Cell Biol. 64, 58-74. doi: 10.1016/j.biocel.2015.03.011

Basu, S., Roberts, E. L., Jones, A. W., Swaffer, M. P., Snijders, A. P., and Nurse, P. (2020). The hydrophobic patch directs cyclin B to centrosomes to promote 
global CDK phosphorylation at mitosis. Curr. Biol. 30, 883.e4-892.e4. doi: 10.1016/j.cub.2019.12.053

Boël, G., Letso, R., Neely, H., Price, W. N., Wong, K. H., Su, M., et al. (2016). Codon influence on protein expression in E. coli correlates with mRNA levels. Nature 529, 358-363. doi: 10.1038/nature16509

Brandis, G., and Hughes, D. (2016). The selective advantage of synonymous codon usage bias in Salmonella. PLoS Genet. 12:e1005926. doi: 10.1371/journal.pgen. 1005926

Braselmann, E., Chaney, J. L., and Clark, P. L. (2013). Folding the proteome. Trends Biochem. Sci. 38, 337-344. doi: 10.1016/j.tibs.2013.05.001

Buhr, F., Jha, S., Thommen, M., Mittelstaet, J., Kutz, F., Schwalbe, H., et al. (2016). Synonymous codons direct cotranslational folding toward different protein conformations. Mol. Cell. 61, 341-351. doi: 10.1016/j.molcel.2016.01.008

Bulmer, M. (1991). The selection-mutation-drift theory of synonymous codon usage. Genetics 129, 897-907.

Chaney, J. L., and Clark, P. L. (2015). Roles for synonymous codon usage in protein biogenesis. Annu. Rev. Biophys. 44, 143-166. doi: 10.1146/annurev-biophys060414-034333

Chaney, J. L., Steele, A., Carmichael, R., Rodriguez, A., Specht, A. T., Ngo, K., et al. (2017). Widespread position-specific conservation of synonymous rare codons within coding sequences. PLoS Comput. Biol. 13:e1005531. doi: 10.1371/journal. pcbi.1005531

Chatenay, D., Cocco, S., Greenbaum, B., Monasson, R., and Netter, P. (2017). "Evolutionary constraints on coding sequences at the nucleotidic level: a statistical physics approach," in Evolutionary Biology: Self/Nonself Evolution, Species and Complex Traits Evolution, Methods and Concepts, ed. P. Pontarotti (Cham: Springer), 329-367. doi: 10.1007/978-3-319-61569-1_18

Choi, H., Gabriel, K., Schneider, J., Otten, S., and McClain, W. H. (2003). Recognition of acceptor-stem structure of tRNA(Asp) by Escherichia coli aspartyl-tRNA synthetase. RNA 9, 386-393. doi: 10.1261/rna.2139703

Dilucca, M., Cimini, G., and Giansanti, A. (2018). Essentiality, conservation, evolutionary pressure and codon bias in bacterial genomes. Gene 663, 178-188. doi: $10.1016 /$ j.gene.2018.04.017

Forsburg, S. L. (1994). Codon usage table for Schizosaccharomyces pombe. Yeast 10, 1045-1047. doi: 10.1002/yea.320100806

Forsburg, S. L., and Rhind, N. (2006). Basic methods for fission yeast. Yeast 23, 173-183. doi: 10.1002/yea.1347

Frenkel-Morgenstern, M., Danon, T., Christian, T., Igarashi, T., Cohen, L., Hou, Y. M., et al. (2012). Genes adopt non-optimal codon usage to generate cell cycledependent oscillations in protein levels. Mol. Syst. Biol. 8:572. doi: 10.1038/msb. 2012.3

Froger, A., and Hall, J. E. (2007). Transformation of plasmid DNA into E. coli using the heat shock method. J. Vis. Exp. 6:253. doi: 10.3791/253

Hanson, G., and Coller, J. (2018). Codon optimality, bias and usage in translation and mRNA decay. Nat. Rev. Mol. Cell Biol. 19, 20-30. doi: 10.1038/nrm.2017.91

Hayles, J., Fisher, D., Woollard, A., and Nurse, P. (1994). Temporal order of S phase and mitosis in fission yeast is determined by the state of the p34cdc2-mitotic B cyclin complex. Cell 78, 813-822. doi: 10.1016/s0092-8674(94)90542-8

Hayles, J., Wood, V., Jeffery, L., Hoe, K. L., Kim, D. U., Park, H. O., et al. (2013). A genome-wide resource of cell cycle and cell shape genes of fission yeast. Open Biol. 3:130053. doi: 10.1098/rsob.130053

Hiraoka, Y., Kawamata, K., Haraguchi, T., and Chikashige, Y. (2009). Codon usage bias is correlated with gene expression levels in the fission yeast Schizosaccharomyces pombe. Genes Cells 14, 499-509. doi: 10.1111/j.13652443.2009.01284.x

Humaidan, D., Breinig, F., and Helms, V. (2018). Adding phosphorylation events to the core oscillator driving the cell cycle of fission yeast. PLoS One 13:e0208515. doi: 10.1371/journal.pone.0208515

Ikemura, T. (1985). Codon usage and tRNA content in unicellular and multicellular organisms. Mol. Biol. Evol. 2, 13-34. doi: 10.1093/oxfordjournals.molbev. a 040335

Ingolia, N. T., Lareau, L. F., and Weissman, J. S. (2011). Ribosome profiling of mouse embryonic stem cells reveals the complexity and dynamics of mammalian proteomes. Cell 147, 789-802. doi: 10.1016/j.cell.2011. 10.002

Jacobs, W. M., and Shakhnovich, E. I. (2017). Evidence of evolutionary selection for cotranslational folding. Proc. Natl. Acad. Sci. U.S.A. 114, 11434-11439. doi: $10.1073 /$ pnas. 1705772114
Jeacock, L., Faria, J., and Horn, D. (2018). Codon usage bias controls mRNA and protein abundance in trypanosomatids. eLife 7:e32496. doi: 10.7554/eLife. 32496

Kanaya, S., Yamada, Y., Kudo, Y., and Ikemura, T. (1999). Studies of codon usage and tRNA genes of 18 unicellular organisms and quantification of Bacillus subtilis tRNAs: gene expression level and species-specific diversity of codon usage based on multivariate analysis. Gene 238, 143-155. doi: 10.1016/s03781119(99)00225-5

Kirchner, S., Cai, Z., Rauscher, R., Kastelic, N., Anding, M., Czech, A., et al. (2017). Alteration of protein function by a silent polymorphism linked to tRNA abundance. PLoS Biol. 15:e2000779. doi: 10.1371/journal.pbio.2000779

Kramer, G., Shiber, A., and Bukau, B. (2019). Mechanisms of cotranslational maturation of newly synthesized proteins. Annu. Rev. Biochem. 88, 337-364. doi: 10.1146/annurev-biochem-013118-111717

Køižek, M., and Køížek, P. (2012). Why has nature invented three stop codons of DNA and only one start codon? J. Theor. Biol. 304, 183-187. doi: 10.1016/j.jtbi. 2012.03.026

Luche, D. D., and Forsburg, S. L. (2009). Cell-cycle synchrony for analysis of S. pombe DNA replication. Methods Mol. Biol. 521, 437-448. doi: 10.1007/978-160327-815-7_24

Michel, C. J., and Thompson, J. D. (2020). Identification of a circular code periodicity in the bacterial ribosome: origin of codon periodicity in genes? RNA Biol. 17, 571-583. doi: 10.1080/15476286.2020.1719311

Morgens, D. W., Chang, C. H., and Cavalcanti, A. R. (2013). Ambushing the ambush hypothesis: predicting and evaluating off-frame codon frequencies in prokaryotic genomes. BMC Genomics 14:418. doi: 10.1186/1471-2164-14-418

Oldenburg, K. R., Vo, K. T., Michaelis, S., and Paddon, C. (1997). Recombinationmediated PCR-directed plasmid construction in vivo in yeast. Nucleic Acids Res. 25, 451-452. doi: 10.1093/nar/25.2.451

Oltra, E., Verde, F., Werner, R., and D’Urso, G. (2004). A novel RING-finger-like protein Inil is essential for cell cycle progression in fission yeast. J. Cell Sci. 117(Pt 6), 967-974. doi: 10.1242/jcs.00946

Pang, Y. L., Abo, R., Levine, S. S., and Dedon, P. C. (2014). Diverse cell stresses induce unique patterns of tRNA up- and down-regulation: tRNA-seq for quantifying changes in tRNA copy number. Nucleic Acids Res. 42:e170. doi: 10.1093/nar/gku945

Patterson, J. O., Rees, P., and Nurse, P. (2019). Noisy cell-size-correlated expression of cyclin B drives probabilistic cell-size homeostasis in fission yeast. Curr. Biol. 29, 1379.e4-1386.e4. doi: 10.1016/j.cub.2019.03.011

Presnyak, V., Alhusaini, N., Chen, Y. H., Martin, S., Morris, N., Kline, N., et al. (2015). Codon optimality is a major determinant of mRNA stability. Cell 160, 1111-1124. doi: 10.1016/j.cell.2015.02.029

Quax, T. E., Claassens, N. J., Söll, D., and van der Oost, J. (2015). Codon bias as a means to fine-tune gene expression. Mol. Cell 59, 149-161. doi: 10.1016/j. molcel.2015.05.035

Rand, J. D., and Grant, C. M. (2006). The thioredoxin system protects ribosomes against stress-induced aggregation. Mol. Biol. Cell 17, 387-401. doi: 10.1091/ mbc.e05-06-0520

Ray, S. K., Baruah, V. J., Satapathy, S. S., and Banerjee, R. (2014). Cotranslational protein folding reveals the selective use of synonymous codons along the coding sequence of a low expression gene. J. Genet. 93, 613-617. doi: 10.1007/s12041014-0429-1

Salazar, J. C., Zúñiga, R., Raczniak, G., Becker, H., Söll, D., and Orellana, O. (2001). A dual-specific Glu-tRNA(Gln) and Asp-tRNA(Asn) amidotransferase is involved in decoding glutamine and asparagine codons in Acidithiobacillus ferrooxidans. FEBS Lett. 500, 129-131. doi: 10.1016/s0014-5793(01)02600-x

Sambrook, J., and Russell, D. (2001). Molecular Cloning A laboratory Manual, 3rd Edn. New York, NY: Cold Spring Harbor Laboratory Press.

Seligmann, H. (2010). The ambush hypothesis at the whole-organism level: off frame, 'hidden' stops in vertebrate mitochondrial genes increase developmental stability. Comput. Biol. Chem. 34, 80-85. doi: 10.1016/j.compbiolchem.2010. 03.001

Seligmann, H. (2011). Error compensation of tRNA misacylation by codonanticodon mismatch prevents translational amino acid misinsertion. Comput. Biol. Chem. 35, 81-95. doi: 10.1016/j.compbiolchem.2011.03.001

Seligmann, H. (2012). Coding constraints modulate chemically spontaneous mutational replication gradients in mitochondrial genomes. Curr. Genomics 13, 37-54. doi: 10.2174/138920212799034802 
Seligmann, H. (2019). Localized context-dependent effects of the "ambush" hypothesis: more off-frame stop codons downstream of shifty codons. DNA Cell Biol. 38, 786-795. doi: 10.1089/dna.2019.4725

Seligmann, H., and Pollock, D. D. (2004). The ambush hypothesis: hidden stop codons prevent off-frame gene reading. DNA Cell Biol. 23, 701-705. doi: 10. 1089/dna.2004.23.701

Shah, P., and Gilchrist, M. A. (2011). Explaining complex codon usage patterns with selection for translational efficiency, mutation bias, and genetic drift. Proc. Natl. Acad. Sci. U.S.A. 108, 10231-10236. doi: 10.1073/pnas.10167 19108

Supek, F. (2016). The code of silence: widespread associations between synonymous codon biases and gene function. J. Mol. Evol. 82, 65-73. doi: 10.1007/s00239-015-9714-8

Torrent, M., Chalancon, G., de Groot, N. S., Wuster, A., and Babu, M. M. (2018). Cells alter their tRNA abundance to selectively regulate protein synthesis during stress conditions. Sci. Signal. 11:eaat6409. doi: 10.1126/scisignal.aat6409

Xu, Y., Ma, P., Shah, P., Rokas, A., Liu, Y., and Johnson, C. H. (2013). Non-optimal codon usage is a mechanism to achieve circadian clock conditionality. Nature 495, 116-120. doi: 10.1038/nature11942

Yanagida, M. (2002). The model unicellular eukaryote, Schizosaccharomyces pombe. Genome Biol. 3:COMMENT2003. doi: 10.1186/gb-2002-3-3comment 2003

Yang, J., Smith, D. K., Ni, H., Wu, K., Huang, D., Pan, S., et al. (2020). SOX4-mediated repression of specific tRNAs inhibits proliferation of human glioblastoma cells. Proc. Natl. Acad. Sci. U.S.A. 117, 5782-5790. doi: 10.1073/ pnas. 1920200117

Zhou, M., Guo, J., Cha, J., Chae, M., Chen, S., Barral, J. M., et al. (2013). Nonoptimal codon usage affects expression, structure and function of clock protein FRQ. Nature 495, 111-115. doi: 10.1038/nature11833

Zhou, M., Wang, T., Fu, J., Xiao, G., and Liu, Y. (2015). Nonoptimal codon usage influences protein structure in intrinsically disordered regions. Mol. Microbiol. 97, 974-987. doi: 10.1111/mmi.13079

Zhou, Z., Dang, Y., Zhou, M., Li, L., Yu, C. H., Fu, J., et al. (2016). Codon usage is an important determinant of gene expression levels largely through its effects on transcription. Proc. Natl. Acad. Sci. U.S.A. 113, E6117-E6125. doi: $10.1073 /$ pnas. 1606724113

Conflict of Interest: The authors declare that the research was conducted in the absence of any commercial or financial relationships that could be construed as a potential conflict of interest.

Copyright (c) 2021 Arias, Martínez, González, Flores-Ríos, Katz, Tello, Moreira and Orellana. This is an open-access article distributed under the terms of the Creative Commons Attribution License (CC BY). The use, distribution or reproduction in other forums is permitted, provided the original author(s) and the copyright owner(s) are credited and that the original publication in this journal is cited, in accordance with accepted academic practice. No use, distribution or reproduction is permitted which does not comply with these terms. 